Article

\title{
Exploring the Road toward Environmental Sustainability: Natural Resources, Renewable Energy Consumption, Economic Growth, and Greenhouse Gas Emissions
}

\author{
Yugang $\mathrm{He}^{1}{ }^{1}, \mathrm{Xiang}_{\mathrm{Li}}{ }^{2}$, Panpan Huang ${ }^{3}$ and Jingnan Wang ${ }^{4, *}$ \\ 1 College of Commerce, Jeonbuk National University, Jeonju 54896, Korea; 1293647581@jbnu.ac.kr \\ 2 College of Tourism and Urban-Rural Planning, Xichang University, Xichang 615000, China; \\ isang1818@163.com \\ 3 College of Business and Economics, Chuang-Ang University, Seoul 06974, Korea; panpanh@126.com \\ 4 College of Economics, Qufu Normal University, Rizhao 276826, China \\ * Correspondence: 13791850836@163.com
}

check for

updates

Citation: He, Y.; Li, X.; Huang, P.;

Wang, J. Exploring the Road toward Environmental Sustainability: Natural Resources, Renewable Energy Consumption, Economic Growth, and Greenhouse Gas Emissions. Sustainability 2022, 14, 1579. https://doi.org/10.3390/ su14031579

Academic Editor: Anna Mazzi

Received: 14 November 2021

Accepted: 24 January 2022

Published: 29 January 2022

Publisher's Note: MDPI stays neutral with regard to jurisdictional claims in published maps and institutional affiliations.

Copyright: (c) 2022 by the authors. Licensee MDPI, Basel, Switzerland. This article is an open access article distributed under the terms and conditions of the Creative Commons Attribution (CC BY) license (https:/ / creativecommons.org/licenses/by/ $4.0 /)$.

\begin{abstract}
Despite the fact that China's economy has grown swiftly since the reform and opening up, the problem of environmental degradation in China has become increasingly significant. Therefore, this paper uses China as an example to examine the dynamic relationship between the highlighted variables (renewable energy consumption, economic growth, oil rent, and natural resources) and greenhouse gas emissions (a proxy for environmental sustainability). Using annual data over the period 1971-2018 and employing the auto-regressive distributed lag bounds approach to perform an empirical analysis, the results suggest that there is a long-run equilibrium relationship between the highlighted variables and greenhouse gas emissions. Specifically, renewable energy consumption and oil rent contribute to environmental sustainability because of their negative effects on greenhouse gas emissions. On the contrary, economic growth and natural resources hinder environmental sustainability due to their positive effects on greenhouse gas emissions. In addition, using the fully modified ordinary least squares approach and dynamic ordinary least squares approach to conduct a robustness test, the results also support the previous findings. To conclude, the findings of this paper may provide some solutions for China's environmental sustainability.
\end{abstract}

Keywords: greenhouse gas emissions; natural resources; renewable energy consumption; economic growth; oil rent; environmental sustainability; auto-regressive distributed lag bounds test

\section{Introduction}

Because of the danger to sustainable development, climate change has become a major topic of debate all around the world [1]. The globe has seen significant economic expansion in recent decades as a result of industrialization and urbanization [2]. China, in particular, has seen a remarkable increase in its gross domestic product rate as a result of fast industrialization, and the whole world now looks up to China because of its strong potential to become the most important world leader [3,4]. China is becoming increasingly prosperous [5,6]. According to China's National Bureau of Statistics, China's GDP increased significantly between 1971 and 2020, from CNY 245.69 billion to CNY 100,878.25 billion, with an average annual growth rate of roughly $8.19 \%$. As a result, a greater level of economic growth, better technology, more environmental rules, and a structural shift in the economy from the industrial (pollution-intensive) to the service sector (information exchange) have reduced environmental pollution $[7,8]$. Increased use of natural resources as a result of increased economic growth, on the other hand, generates major environmental issues $[9,10]$. Deforestation, water shortage, oil over-exploitation, and climate change are all problems caused by the irresponsible use of natural resources in developing countries. Unfortunately, China's rapid economic expansion has resulted in a slew of environmental challenges, chief among them greenhouse gas emissions [11-13]. 
There are several solutions available to minimize greenhouse gas emissions in the face of the unsustainable development of natural resources, energy consumption, economic growth, and greenhouse gas emissions, as advocated by different experts. For example, Kirikkaleli and Adebayo [14] proposed that we could reduce greenhouse gas emissions by discouraging the use of non-renewable energy and increasing the amount of renewable energy. Magazzino et al. [15] thought that a complete transition from fossil to renewable resources could reduce greenhouse gas emissions. Ponce and Khan [16] came to the conclusion that improving energy efficiency was a substantial and successful strategy for reducing greenhouse gas emissions. Yuping et al. [17] discovered that globalization had reduced greenhouse gas emissions. In fact, many academics have proposed various strategies to limit greenhouse gas emissions [18-20]. Meanwhile, among the alternative solutions evaluated in the fourth assessment report of the International Panel on Climate Change were energy conservation and efficiency, a transition away from fossil fuels, use of new renewable energy sources, nuclear power, and carbon capture and storage. In reality, any portfolio of mitigation alternatives for reducing greenhouse gas emissions should be thoroughly evaluated, including their diverse mitigation potential, their contribution to sustainable development, and all related risks and costs.

To achieve the goal of environmental sustainability, this paper uses China as a case study to explore the issues of natural resources, renewable energy consumption, economic growth, oil rent, and greenhouse gas emissions over the period 1971-2018. The autoregressive distributed lag bounds test was used in the study to evaluate the link between the highlighted variables. This approach has been widely documented in recent literature and is recommended over the Johansen approach of co-integration since it allows for the flexibility of changing lag lengths, avoiding endogeneity, and authenticating even tiny sample numbers to achieve superior results. The auto-regressive distributed lag bounds approach can be used regardless of integration order, i.e., I(0) or I(1). The modified autoregressive distributed lag model's simple linear transformation may be used to create the dynamic error correction model, which integrates short-term dynamics with long-term equilibrium without surrendering any long-term information. This paper shows, based on factual evidence, that natural resources and economic expansion worsen the environment, but renewable energy consumption and oil rent enhance environmental sustainability. Furthermore, this study also provides a theoretical foundation for China's decision makers to minimize greenhouse gas emissions.

This work makes two contributions to the current literature. Firstly, a large number of previous studies [21-25] have examined the different dynamic relationships between economic growth and greenhouse gas emissions in China. However, the dynamic link between renewable energy consumption, economic growth, natural resources, and greenhouse gas emissions in China is little documented. The results of this paper fill this gap. Secondly, China's rapid economic expansion is primarily reliant on sacrificing the environment and using a large amount of fossil fuel, which will lead to environmental degradation. The conclusions of this paper provide some alternatives for their coordinated growth.

The remainder of this paper is divided into four sections. Section 2 reviews previous literature. Section 3 shows the variable description and methodology specification. Section 4 presents findings and discussions. Section 5 provides the conclusion, suggestions, and future directions.

\section{Literature Review}

In this section, more emphasis will be placed on reviewing past research on the subject of this study. In this domain of environmental pollution, economic growth, and energy consumption, which has been extensively researched and documented in the literature, many drivers, analytic approaches, sample data, and nation selection have been employed. Previous research findings aid in providing a greater understanding of the relationship between the investigated variables and greenhouse gas emissions. In a carbon function with natural resource rent, Bekun et al. [26] studied the long-run and causal relationship 
between renewable energy consumption and economic development. Using data from 1996 to 2014 for a group of EU-16 countries and employing the Kao test to conduct an empirical analysis, they found that renewable energy consumption, economic development, carbon dioxide emissions, and natural resource rent were shown to be co-integrated. Specifically, renewable energy consumption enhanced environmental quality, and natural resource rent exacerbated carbon dioxide emissions. Subsequently, Muhammad et al. [27] used data from 1991 to 2018 and employed a fixed effects model to investigate the effect of natural resources, economic growth, and renewable energy consumption on environmental degradation with samples from BRICS, global, developed, and developing countries. They found that renewable energy consumption aided in the reduction in environmental deterioration. However, the primary elements that contributed to environmental deterioration were economic growth and total natural resources. Afterwards, Agboola et al. [28] used Saudi Arabia as the sample to confirm the dynamic relationship among total natural resources, economic growth, and carbon dioxide emissions over the period 1971-2016. Adopting the Pesaran Bounds test and the modified Wald test of the Toda-Yamamoto methodology to conduct empirical analysis, they found that in the short and long term, economic growth-induced environmental deterioration had grown by $0.952 \%$ and $0.625 \%$, respectively. Additionally, total natural resource rent and carbon dioxide emissions had a considerable positive relationship, which implied that an excessive reliance on natural resources had an impact on environmental sustainability. Crucially, the above-mentioned findings were also corroborated by a large number of investigations [29-34].

With the case of Pakistan, Hassan et al. [35] used the auto-regressive distributive lag model to investigate the effect of natural resources and economic growth on ecological footprints. They found that natural resources had a beneficial influence on an ecological footprint that degraded environmental quality, and natural resources served to support the environmental Kuznets hypothesis. In the meantime, because of economic development, the Intergovernmental Panel on Climate Change reported that energy consumption remained the primary source of anthropogenic greenhouse gas emissions. Therefore, Joshua and Bekun [36] investigated the factors that contributed to environmental degradation in South Africa from 1970 to 2017. They found the long-run equilibrium link between pollutant emissions, economic growth, and total natural resource rent via Pesaran's Bounds test. They emphasized that total natural resources rent contributed significantly to South Africa's pollution emissions. Besides, global warming was a severe challenge for most economies, and the rising industrialized seven nations were not immune. Gyamfi et al. [37] investigated the coal rent-energy-environmental nexus using panel ordinary least squares and panel quantile regression between 1990 and 2016. They found that real GDP had a positive effect on carbon dioxide emissions. Importantly, they also found that renewable energy negatively affected carbon dioxide emissions. Another way of saying this was that environmental quality increased by $0.588 \%$ for every $1 \%$ increase in renewable energy consumption. Notably, these investigations [38-40] were also in line with the previously mentioned literature.

The Gulf Cooperation Council region's reliance on oil production may have environmental effects. Taking into account spatial links from 1980 to 2014, Mahmood and Furqan [41] investigated the nonlinear impacts of economic growth and oil rents in six Gulf Cooperation Council nations on greenhouse gas emissions. Applying the fixed effects and spatial Durbin model to perform an empirical analysis, they discovered an inverted U-shaped association between economic growth and greenhouse gas emissions, as well as a relationship between oil rents and greenhouse gas emissions. In nine Latin American countries from 1975 to 2013, Ozturk [42] also studied this proposition. Their results, estimated by the pooled, seemingly unrelated regression, supported the above achievement. With 37 oil-producing nations from 1989 to 2019, Sadik-Zada and Loewenstein [43] provided a survey that looked at the income-environment links of oil-producing nations as well as other factors of air pollution in their distinct surroundings. For the first time, they used a fixed effect, nonparametric, time-varying coefficient panel data estimator to study 
this topic. In their empirical findings, the quantity of oil rents and the industrial sector's percentage of GDP were found to be key drivers of carbon dioxide emissions. Similarly, with 15 oil-producing countries over the period 1980-2010, Ike et al. [44] employed the novel method of moments quantile regression with fixed effects to study the effect of oil production on carbon dioxide emissions. They found that from the first to the sixth quantiles, oil production raised carbon dioxide emissions substantially, with a stronger influence at the lowest quantile and a lower effect at the highest. In addition to the above literature, other scholars' empirical investigations also supported their achievements [45-48].

Except for the above investigations, a huge number of academics have sought to evaluate the distinct patterns in the link between greenhouse gas emissions and economic growth indicators for China based on the information from the aforementioned studies. There is, however, a paucity of research in China on the dynamic link between the highlighted variables and greenhouse gas emissions. The importance of this work cannot be overstated, as it will help policymakers understand the factors that influence greenhouse gas emissions in China. In addition, it makes policy proposals for addressing the issue of greenhouse gas emissions in a fast-growing economy while aiming for sustainable economic growth.

\section{Variable Description and Methodology Specification}

\subsection{Variable Description and Model Construction}

This paper uses a time series analysis to investigate the dynamic relationship between the highlighted variables (natural resources, renewable energy consumption, economic growth) and greenhouse gas emissions in China. Due to the data availability, the annual time series data from 1971 to 2018 was employed. Greenhouse gases are compound gases that trap heat or long-wave radiation in the atmosphere. Their existence in the atmosphere raises the temperature of Earth's surface. Shortwave radiation or sunlight readily travels through these gases and the atmosphere. The earth's surface absorbs this radiation, which is then emitted as heat or long-wave radiation. Due to their molecular structure, greenhouse gases absorb the heat emitted and either hold it in the atmosphere or re-emit it back to the ground. The "greenhouse effect" is the term for this heat-trapping phenomena. Since China's reform and opening up, the concentration of greenhouse gases has hastened the greenhouse effect, resulting in environmental devastation. The data of greenhouse gas emissions were collected from the World Bank. Two considerations underpin the usage of greenhouse gas emissions as a proxy for environmental sustainability. One is that most of the greenhouse gas emissions come from the development of heavy industry and automobile exhaust throughout the world. Once the greenhouse gas exceeds the atmospheric standard, it will cause the greenhouse effect, increase the global temperature, and threaten human survival. Therefore, controlling greenhouse gas emissions has become a major problem facing all mankind. Another is that it is a rigorous and widely acknowledged scientific assessment of environmental sustainability that is internationally comparable [49-52].

The control variables are typical in the empirical literature on greenhouse gas emissions to follow previous studies and to minimize any omitted variable bias in the econometric analysis. Following Vasylieva et al. [53], Lyeonov et al. [54], and Squalli [55], renewable energy consumption is introduced in this paper. Following Lapinskienè et al. [56], Lu [57], and Kim [58], economic growth is introduced in this paper. Following Morrow et al. [59], Van Ruijven and Van Vuuren [60], and Germer and Sauerborn [61], oil rent is introduced in this paper. Following Tufail et al. [62] and Huang et al. [63], natural resources is introduced in this paper. All these control variables from 1971 to 2018 were sourced from the World Bank. More information about these variables used in this paper can be found in Table 1. 
Table 1. Variable description.

\begin{tabular}{ccc}
\hline Variable & Form & Definition \\
\hline $\begin{array}{c}\text { Greenhouse gas emissions } \\
\text { Renewable energy }\end{array}$ & gge & Total greenhouse gas emissions (unit: million tons) \\
consumption & ec & Amount of renewable energy consumed \\
Economic growth & eg & GDP (constant 2015 USD, and unit: billion USD) \\
Oil rent & or & Oil rents (\% of GDP) \\
Natural resources & nr & Total natural resources rents (\% of GDP) \\
\hline
\end{tabular}

Note: All of this information was gathered from the World Bank.

The functional form of the association between the highlighted variables (natural resources, renewable energy consumption, economic growth, and oil rent) and greenhouse gas emissions is specified as follows:

$$
\operatorname{gge}_{\mathrm{t}}=\mathrm{f}\left(\mathrm{ec}_{\mathrm{t}}, \mathrm{eg}_{\mathrm{t}}, \mathrm{or}_{\mathrm{t}}, \mathrm{nr}_{\mathrm{t}}\right)
$$

Following Sterpu et al. [64], inducing stationarity in the variance-covariance matrix is easily achieved by transforming linear models into logs. As a result, Equation (1) can be rewritten as follows:

$$
\log \operatorname{gge}_{\mathrm{t}}=\mathrm{a}_{0}+\mathrm{a}_{1} \log \mathrm{ec}_{\mathrm{t}}+\mathrm{a}_{2} \log \mathrm{eg}_{\mathrm{t}}+\mathrm{a}_{3} \log \mathrm{or}_{\mathrm{t}}+\mathrm{a}_{4} \log \mathrm{nr}_{\mathrm{t}}+\varepsilon_{\mathrm{t}}
$$

where $\mathrm{a}_{0}$ denotes the constant; $\left[\mathrm{a}_{1}, \mathrm{a}_{4}\right]$ denote the coefficients to be estimated; $\varepsilon_{\mathrm{t}}$ denotes the white noise. In Section 4, Equation (2) will be used first to investigate the link between the highlighted variables and greenhouse gas emissions.

\subsection{Econometric Model Estimation Approach}

Pesaran et al. [65] developed the auto-regressive distributed lag bounds testing approach to estimate long-run and short-run co-integration. The auto-regressive distributed lag approach has been widely employed due to its several advantages. Because the sample size in this paper only includes 48 observations (the period over 1971-2018), Pesaran et al. [65] and Pesaran and Shin [66] believed that the auto-regressive distributed lag approach was better suited since it produced reliable and consistent estimates even with a small sample size. The auto-regressive distributed lag approach, once again, has no auto-correlation problems, and the issue of endogeneity is solved by selecting a proper lag length. It may be used to identify whether the highlighted variables are partially or entirely stationary, i.e., $\mathrm{I}(0)$, I(1), or jointly. This approach also yields a single model with both long- and short-run co-integration vectors. Using the unrestricted error correction model, Equation (2) can be transformed as follows:

$$
\begin{aligned}
\Delta \log \operatorname{gge}_{\mathrm{t}}=\mathrm{b}_{0} & +\sum_{\mathrm{k}=1}^{\mathrm{p}} \mathrm{b}_{1} \Delta \log \operatorname{gge}_{\mathrm{t}-\mathrm{k}}+\sum_{\mathrm{k}=0}^{\mathrm{p}} \mathrm{b}_{2} \Delta \log \mathrm{ec}_{\mathrm{t}-\mathrm{k}}+\sum_{\mathrm{k}=0}^{\mathrm{p}} \mathrm{b}_{3} \Delta \log \mathrm{eg}_{\mathrm{t}-\mathrm{k}} \\
& +\sum_{\mathrm{k}=0}^{\mathrm{p}} \mathrm{b}_{4} \Delta \log \mathrm{or}_{\mathrm{t}-\mathrm{k}}+\sum_{\mathrm{k}=0}^{\mathrm{p}} \mathrm{b}_{5} \Delta \log \mathrm{nr}_{\mathrm{t}-\mathrm{k}}+\mathrm{b}_{6} \log \operatorname{gge}_{\mathrm{t}-1} \\
& +\mathrm{b}_{7} \log \mathrm{ec}_{\mathrm{t}-1}+\mathrm{b}_{8} \log \mathrm{eg}_{\mathrm{t}-1}+\mathrm{b}_{9} \log \mathrm{or}_{\mathrm{t}-1}+\mathrm{b}_{10} \log \mathrm{nr}_{\mathrm{t}-1} \\
& +\mathrm{b}_{11} \mathrm{du}+\varepsilon_{\mathrm{t}}
\end{aligned}
$$

where $b_{0}$ denotes the constant; $\Delta$ denotes the first difference operator; $\left[b_{1}, b_{5}\right]$ denote the short-run parameters to be estimated; $\left[b_{6}, b_{10}\right]$ denote the long-run parameters to be estimated; and du denotes the structural break dummy variable. The F-test was employed on the equation to detect the joint significance of lagged levels. The null hypothesis $\left(\mathrm{H}_{0}\right)$ was designed as follows: $b_{6}=b_{7}=b_{8}=b_{9}=b_{10}=0$. This denotes that there is no 
co-integration. On the contrary, the alternative hypothesis $\left(\mathrm{H}_{1}\right)$ was designed as follows: $\mathrm{b}_{6} \neq \mathrm{b}_{7} \neq \mathrm{b}_{8} \neq \mathrm{b}_{9} \neq \mathrm{b}_{10} \neq 0$. This denotes that there is a co-integration.

The first step in the auto-regressive distributed lag co-integration approach is bounds testing, which is based on the F-test. To determine co-integration, the F-statistic is compared with the tabulated critical values. Narayan and Smyth [67] calculated two critical value bounds for a small sample size including 30 to 80 observations, while Persan and Pesaran [68] calculated two critical value bounds for a large sample size including 500 to 1000 observations due to the non-standard distribution of the F-test employed in the bounds test.

The lower bound assumes that variables are $\mathrm{I}(0)$, whereas the upper bound assumes that variables are I(1). Specifically, if the estimated F-statistic exceeds the upper critical value, evidence of co-integration is present. In contrast, if the estimated F-statistic is less than the lower critical value, no evidence of co-integration is found. Otherwise, if the F-statistic locates between the upper critical value and lower critical value, the test becomes inconclusive.

It should be highlighted that if any of renewable energy consumption, economic growth, oil rent, and natural resources is changed, greenhouse gas emissions, a measure of environmental sustainability, may not alter the path of long-run equilibrium. The estimated error correction model captures the speed at which greenhouse gas emissions adjusts from the short-run to the long-run equilibrium. The error correction model is shown as follows:

$$
\begin{aligned}
\Delta \log \operatorname{gge}_{\mathrm{t}}=\mathrm{c}_{0} & +\sum_{\mathrm{k}=1}^{\mathrm{p}} \mathrm{c}_{1} \Delta \log \operatorname{gge}_{\mathrm{t}-1}+\sum_{\mathrm{k}=0}^{\mathrm{p}} \mathrm{c}_{2} \Delta \log \mathrm{ec}_{\mathrm{t}-\mathrm{k}}+\sum_{\mathrm{k}=0}^{\mathrm{p}} \mathrm{c}_{3} \Delta \log \mathrm{eg}_{\mathrm{t}-\mathrm{k}} \\
& +\sum_{\mathrm{k}=0}^{\mathrm{p}} \mathrm{c}_{4} \Delta \log \mathrm{or}_{\mathrm{t}-\mathrm{k}}+\sum_{\mathrm{k}=0}^{\mathrm{p}} \mathrm{c}_{5} \Delta \log \mathrm{nr}_{\mathrm{t}-\mathrm{k}}+\mathrm{c}_{6} \mathrm{du}+\lambda \mathrm{ect}_{\mathrm{t}-1}+\varepsilon_{\mathrm{t}}
\end{aligned}
$$

where $c_{0}$ denotes the constant; $\left[c_{1}, c_{5}\right]$ and $\lambda$ denote the short-run parameters to be estimated; ect $_{\mathrm{t}-1}$ denotes the error correction term (the lag of the residual); and $\lambda$ denotes the greenhouse gas emissions converging to the long-run equilibrium relationship by about $\lambda \%$ speed of adjustment in every year by the changes in renewable energy consumption, economic growth, oil rent, and natural resources.

\section{Findings and Discussions}

In this section, significant attention will be paid to discussing how to understand the study's empirical findings. We begin with a simple summary, which includes measures of dispersion and central tendencies of the variables listed in Section 4.1.

\subsection{Estimation of Basic Statistics}

The basic summary statistics include the analysis of the mean, maximum, minimum, and standard deviation of each variable used in this paper. The results are reported in Table 2.

Table 2. Results of estimation of basic statistics.

\begin{tabular}{cccccc}
\hline \multicolumn{7}{c}{ Panel A: Variable Characteristic Description } \\
\hline Variable and Statistics & log gge & $\log$ ec & $\log$ eg & $\log$ or & $\log \mathrm{nr}$ \\
Mean & 3.665 & 2.314 & 3.169 & 2.261 & 2.639 \\
Maximum & 4.092 & 2.470 & 3.983 & 3.072 & 3.284 \\
Minimum & 3.282 & 2.195 & 2.470 & 0.918 & 1.912 \\
Standard deviation & 0.255 & 0.057 & 0.491 & 0.461 & 0.357 \\
Observations & 48 & 48 & 48 & 48 & 48 \\
\hline
\end{tabular}

Table 2 reports the results of both the variable characteristic description and the analysis of the correlation test. As for the results in Panel A, the mean for greenhouse gas emissions was 3.665 , with a standard deviation of 0.255 . This means that pollutant emissions are increasing; the mean for renewable energy consumption was 2.314 , with 
a standard deviation of 0.057 . This indicates that renewable energy usage is on the rise, although it varies slightly; the mean for economic growth was 3.169, with a standard deviation of 0.491 . This shows that economic development is continuing, but that it relatively erratic; the mean for oil rent was 2.261 , with a standard deviation of 0.461 . This suggests that the share of oil rent in GDP is rising, although it varies greatly; the mean for natural resources was 2.639 , with a standard deviation of 0.357 . This shows that the percentage of total natural resource rents to GDP is growing, but that this proportion swings significantly.

Moreover, to perform the unit root test in the following subsection, we used graphs to explore the properties of the investigated variables in this paper. The results are shown in Figure 1.
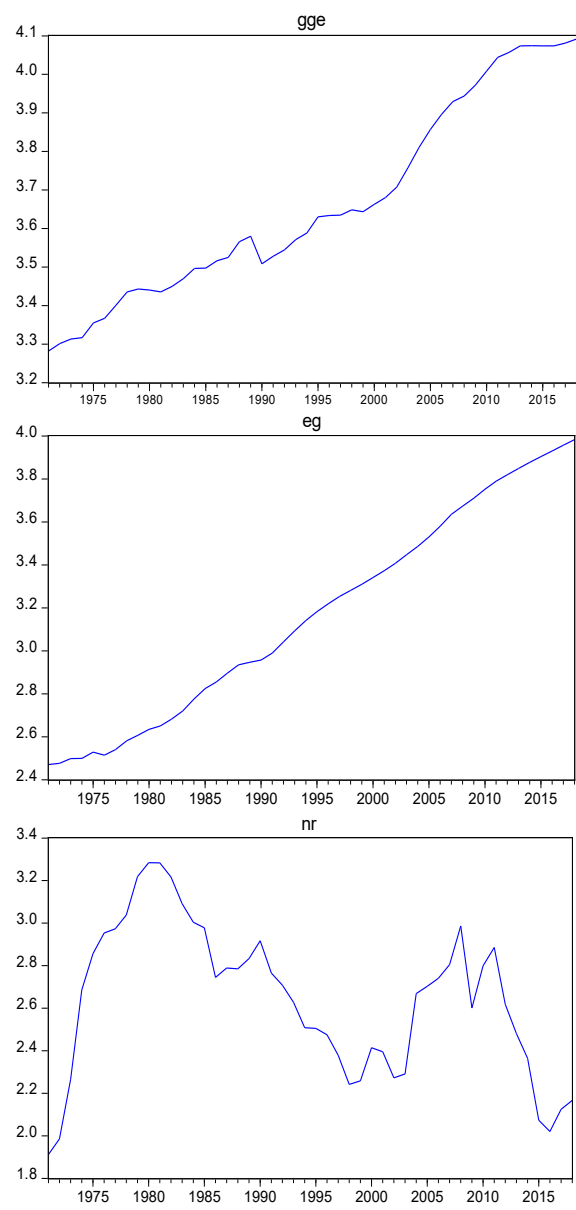
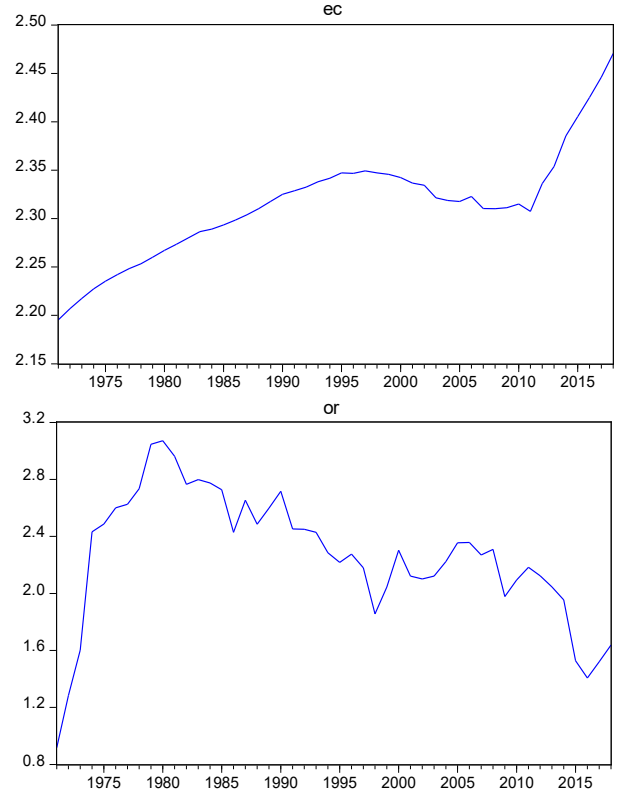

Figure 1. Graphical plots of (gge), (ec), (eg), (or), and (nr).

Figure 1 provides the graphical plots of greenhouse gas emissions (gge), renewable energy consumption (ec), economic growth (eg), oil rent (or), and natural resources (nr). The plotted variables exhibited some structural breaks. Therefore, the break-point time series approach was used to keep the results reliable and robust.

\subsection{Unit Root Test and Auto-Regressive Distributed Lag Bounds Test}

When undertaking empirical analysis in econometric models, Lee and Strazicich [69] and Harvey et al. [70] suggested that keeping all variables stable was critical. Therefore, the goal of this subsection is to investigate the outlined variables' stationarity properties. In this paper, both the augmented Dickey-Fuller test (ADF-test) and the Phillips-Perron test (PP-test) were used to conduct the unit root test, according to Carrion-i-Silvestre et al. [71] and Xiao [72]. Furthermore, due to the investigated variables showing structural breaks, the break-point unit root test was also employed to supplement the results of ADF-test 
and PP-test $[73,74]$. According to results of unit root tests, the auto-regressive distributed lag bounds test was conducted. Table 3 summarizes these results in Panel C, Panel D, and Panel E.

Table 3. Results of unit root test and bounds test.

\begin{tabular}{|c|c|c|c|c|c|}
\hline \multicolumn{6}{|c|}{ Panel B: Unit Root Test } \\
\hline Statistic Level & log gge & $\log \mathrm{ec}$ & $\log$ eg & $\log$ or & $\log n r$ \\
\hline ADF-test & -1.694 & -2.795 & $-3.249 *$ & $-4.868^{* * *}$ & -3.157 \\
\hline PP-test & -1.587 & -1.393 & $-3.842 * *$ & $-5.484^{* * *}$ & -3.137 \\
\hline First Difference & gge & ec & eg & or & $\mathrm{nr}$ \\
\hline ADF-test & $-5.069 * * *$ & $-5.137^{* * *}$ & $-5.949 * * *$ & $-5.949 * * *$ & $-5.447^{* * *}$ \\
\hline PP-test & $-5.066^{* * *}$ & $-4.445^{* * *}$ & $-4.224^{* * *}$ & $-5.913^{* * *}$ & $-5.466^{* * *}$ \\
\hline \multicolumn{6}{|c|}{ PanelC: Zivot and Andrews Unit Root Tests with Structural Breaks } \\
\hline Statistic Level & log gge & $\log \mathrm{ec}$ & $\log$ eg & $\log$ or & $\log n r$ \\
\hline Z-A-test & -3.113 & -4.106 & -1.362 & $-4.614^{* *}$ & -3.332 \\
\hline Break year & 1990 & 2011 & 1991 & 1990 & 1990 \\
\hline First Difference & log gge & $\log$ ec & $\log$ eg & $\log$ or & $\log n r$ \\
\hline Z-A-test & $-6.962 * * *$ & $-5.102 * * *$ & -5.391 & $-7.324^{* * *}$ & $-6.437^{* * *}$ \\
\hline Break year & 2001 & 2011 & 1976 & 1976 & 1976 \\
\hline \multicolumn{6}{|c|}{ PanelD: Auto-Regressive Distributed Lag Bounds Test } \\
\hline \multicolumn{6}{|c|}{ Model : $\operatorname{gge}_{\mathrm{t}}=\mathrm{f}\left(\mathrm{ec}_{\mathrm{t}}, \mathrm{eg}_{\mathrm{t}}, \mathrm{or}_{\mathrm{t}}, \mathrm{nr}_{\mathrm{t}}\right)$} \\
\hline Test Sta & & \multicolumn{2}{|c|}{ Value } & \multicolumn{2}{|c|}{$\mathrm{K}$} \\
\hline F-stati & & \multirow{2}{*}{\multicolumn{2}{|c|}{$6.956^{* * *}$}} & \multicolumn{2}{|c|}{4} \\
\hline \multicolumn{4}{|c|}{ Critical Value Bounds } & & \\
\hline Signific & & \multicolumn{2}{|c|}{$\mathrm{I}(0)$ bounds } & \multicolumn{2}{|c|}{$\mathrm{I}(1)$ bounds } \\
\hline $10^{\circ}$ & & \multicolumn{2}{|c|}{2.20} & \multicolumn{2}{|c|}{3.09} \\
\hline $5 \%$ & & \multicolumn{2}{|c|}{2.56} & \multicolumn{2}{|c|}{3.49} \\
\hline $1 \%$ & & \multicolumn{2}{|c|}{3.29} & \multicolumn{2}{|c|}{4.37} \\
\hline Section & & \multicolumn{4}{|c|}{ auto-regressive distributed lag $(1,0,1,0,0)$} \\
\hline
\end{tabular}

Note: McKinnon is the foundation of ADF test's critical values. For the ADF and Phillips-Perron tests, the null hypothesis was that a series has a unit root. The Akaike information criterion was used to select the optional. In Panel D, the maximum lag was set to two. ${ }^{*} 10 \%$ significant level. ${ }^{* *} 5 \%$ significant level. ${ }^{* * *} 1 \%$ significant level.

Table 3 reports the results of the unit root test and auto-regressive distributed lag bounds test. Taking the results of Panel B into consideration, greenhouse gas emissions, renewable energy consumption, and natural resources were determined to be non-stationary at their own levels, while economic growth and oil rent were stationary. Fortunately, after taking the first difference, all of these variables become stationary at $1 \%$ significant level. To summarize, the ADF-test and PP-test presented the unit root properties, which are in a mixed order of integration. However, the occurrence of structural breaks is a key problem in time series analysis. Because the ADF and PP unit root tests cannot deal with structural breaks, the Zivot and Andrews unit root tests with structural breaks are provided in Panel C. The results suggest that all variables with a structural break are integrated at I(1). Greenhouse gas emissions had a break in 2001. The break in 2001 in greenhouse gas emissions may be linked to China's accession to the WTO. In order to boost the economy, a great number of extremely polluting firms were imported into China during that period. Although China's economy has grown swiftly, China's environmental degradation has also grown significantly. As a result, in the auto-regressive distributed lag estimations, this paper included a dummy variable for the break year. As revealed by the bounds testing technique in Table 3 (Panel D), it was possible to detect a long-run equilibrium relationship between the described variables. The results of Table 3 in Panel D suggest that a long-run equilibrium relationship between the described variables can be confirmed. Concretely, the value of F-statistics was greater than boundaries I( 0$)$ and I(1) at $1 \%$ significant level. In other words, the outlined variables were convergent across the sampling time. In the next step, the long-term and short-term relationships between the highlighted variables will be analyzed. 


\subsection{Auto-Regressive Distributed Lag Model for Short- and Long-Run Analysis}

Following Sun et al. [75] and Pata and Caglar [76], the purpose of this subsection is to examine the magnitude and influence of the long-run and short-run relationships between the variables and greenhouse gas emissions. The estimating results of the auto-regressive distributed lag for the short-run and long-run regressions are presented in Table 4.

Table 4. Results of auto-regressive distributed lag model for short and long-run analysis.

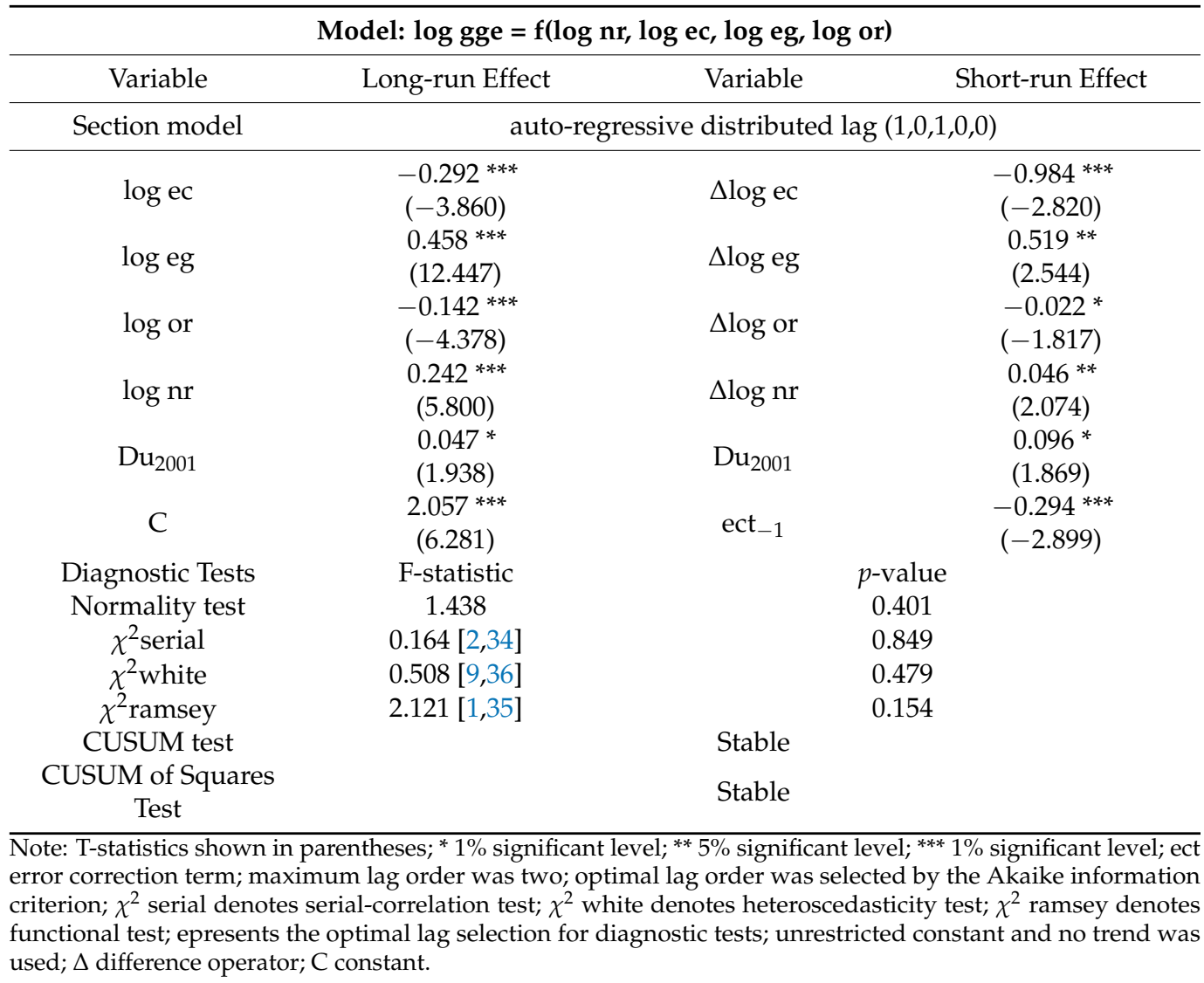

Table 4 presents the results of the greenhouse gas emissions equation. To thoroughly interpret and discuss the results in Table 4 , we will break them down into five stages. For the first stage, it was found that the effect of renewable energy consumption on greenhouse gas emissions was negative at the $1 \%$ significant level. To put it another way, a $1 \%$ increase in renewable energy consumption results in a $0.292 \%$ reduction in long-run greenhouse gas emissions and a $0.984 \%$ reduction in short-run greenhouse gas emissions. These findings imply that China's present renewable energy consumption is reducing greenhouse gas emissions. This is inextricably linked to China's shift in energy policy (gradually replacing fossil energy with clean energy to promote environmental sustainability). Furthermore, this is consistent with China's economic development and environmental goals. That is, in addition to attaining long-term economic growth, we must also maintain the environment's long-term sustainability [77,78]. Moreover, this finding is in line with the United Nations Sustainable Development Goals, which emphasize access to clean, responsible energy usage and climate change mitigation, as is customary practice across the world. In summary, renewable energy consumption can help to ensure China's environmentally sustainable future. This result is consistent with Chen et al. [79] and Dong et al. [80].

For the second stage, we detected statistically positive effects of economic growth on greenhouse gas emissions, with a $1 \%$ rise in economic growth increasing and depleting the environment by $0.458 \%$ and $0.519 \%$, respectively, in both the short and long run. As a result, it appears that an increase in human activities that promotes economic growth 
degrades the environment's quality. This result is consistent with Wang et al. [81] and Govindaraju and Tang [82]. This discovery, of course, has policy implications in China. This poses a quandary, in that there is ongoing pressure to boost economic development and raise residents' living standards, while the aforesaid economic trajectory has intrinsic environmental costs and repercussions. As a result, prudence is required in controlling economic activity without compromising economic growth.

For the third stage, it was observed that oil rent negatively affects greenhouse gas emissions. That is to say, oil rent has been discovered to enhance China's environmental quality. Specifically, a $1 \%$ rise in oil rent results in a $0.142 \%$ reduction in long-run greenhouse gas emissions and a $0.022 \%$ reduction in short-run greenhouse gas emissions. The possible reason for this is linked to the fact that oil emissions in China are low in comparison to other energy sources such as coal, which release significant pollution. Reducing oil rent emissions implies that the country's oil resources may be utilized to diversify the energy sector and portfolio while also implementing other environmental sustainability strategies. As a result, it refers to the nature of China's oil structure as well as the country's environmental sustainability. In addition, China's awareness of a clean and sustainable energy portfolio, notably during the Xi Jinping period, appears to be the cause for this very fair conclusion. When compared to previous studies [83-85], this is an intriguing discovery.

For the third stage, it was discovered that the effect of natural resources on greenhouse gas emissions is positive in the long and short run. Specifically, a 1\% increase in natural resources results in a $0.242 \%$ rise in long-run greenhouse gas emissions and a $0.046 \%$ increase in short-run greenhouse gas emissions. Natural resources, in other words, degrade the environment's quality. If conservation management alternatives are overlooked, this shows that China's over-reliance on natural resources has an influence on environmental sustainability. This outcome is consistent with Chen and Chen [86], Balsalobre-Lorente et al. [87], and Zhou et al. [88].

For the fourth stage, the dummy variable and the error correction term were taken into account. The coefficients of the dummy variable were positive and significant at the $10 \%$ level. Concretely, a $1 \%$ increase in dummy variable results in a $0.047 \%$ increase in long-run greenhouse gas emissions and a $0.096 \%$ increase in short-run greenhouse gas emissions. In other words, after 2001, the environmental deterioration in China worsened. This finding is consistent with the real situation of China. A possible reason for this phenomenon is that in 2001, there was a hiatus in greenhouse gas emissions. The increase in greenhouse gas emissions in 2001 might be attributed to China's WTO membership. During that time, a large number of severely polluting enterprises were introduced to China in order to grow the economy. Although China's economy has developed rapidly, so has China's environmental degradation. Meanwhile, the coefficient of error correction term is negative and significant in statistics. The error correction term, which demonstrates $29.4 \%$ annual speed of convergence with the shocks of natural resource, renewable energy consumption, economic growth, and oil rent, validates the long-run relationship.

For the fifth stage, the discussion turns to diagnostic tests. The normal distribution test, serial correlation test, heteroscedasticity test, and functional misspecification test were used to examine the residuals of the estimated model. The results reveal that serial correction and heteroscedasticity do not appear. Whereas the model's functional form is appropriately recognized and stated, there is no information to support the residual normal distribution. Moreover, the cumulative sum and cumulative sum squared tests were used to ensure the model's stability. Results from Figure 2, within 5\% critical bounds, support the position that the investigated variables in the error correction model are stable. 


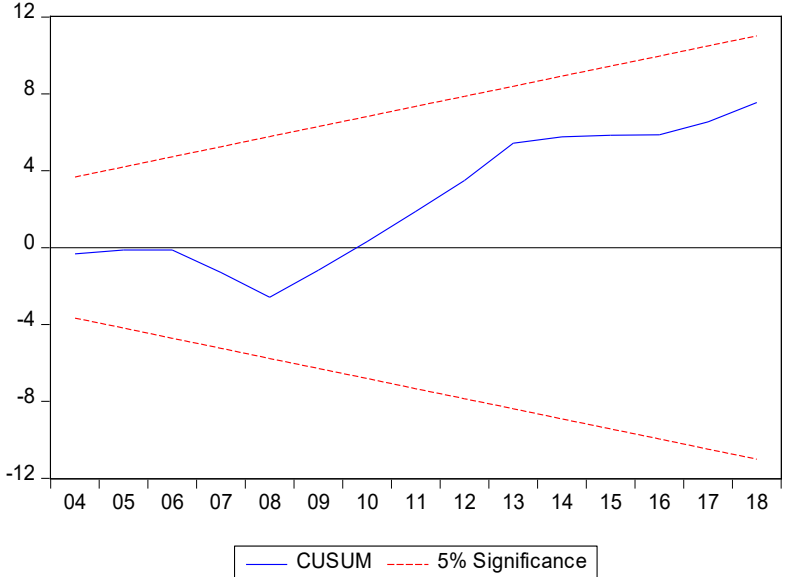

(a)

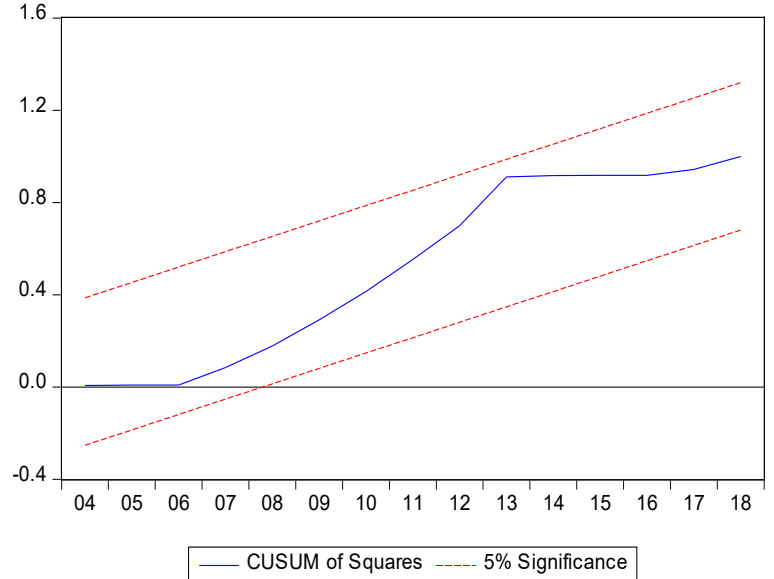

(b)

Figure 2. Diagnostic test results. (a) Plot of cumulative sum of recursive residuals; (b) Plot of cumulative sum of squares of recursive residuals.

\subsection{Robustness Test}

Following the example of Anwar et al. [89], Yao et al. [90], and Wolde-Rufael and Idowu [91], both the fully modified ordinary least squares (FMOLS) approach and dynamic ordinary least squares (DOLS) approach were used to investigate the effect of the highlighted variables on greenhouse gas emissions as a robustness test. The results of robustness test are presented in Table 5.

Table 5. Results of robustness test.

\begin{tabular}{ccc}
\hline & Dependent Variable: Greenhouse Gas Emissions & \\
\hline Approach & FMOLS & DOLS \\
\hline \multirow{2}{*}{$\log$ ec } & $-0.172^{* * *}$ & $-0.687^{* * *}$ \\
& $(-8.885)$ & $(-7.763)$ \\
$\log$ eg & $0.465^{* * *}$ & $0.496^{* * *}$ \\
& $(13.760)$ & $(8.001)$ \\
$\log$ or & $-0.126^{* * *}$ & $-0.235^{* * *}$ \\
& $(-3.856)$ & $(-4.077)$ \\
$\log \mathrm{nr}$ & $0.233^{* * *}$ & $0.137^{* *}$ \\
& $(6.005)$ & $(2.085)$ \\
Du 2001 & $0.054^{* *}$ & $0.169^{* * *}$ \\
& $(2.462)$ & $(4.199)$
\end{tabular}

Note: T-statistics shown in parentheses; ${ }^{* *} 5 \%$ significant level; ${ }^{* * *} 1 \%$ significant level; automatic leads and lags specification (lead $=2$ and lag $=2$ based on AIC criterion, $\max =2$ ); long-run variance estimate (Bartlett kernel, Newey-West fixed bandwidth $=4.0000)$.

As results of Table 5 indicate, we found that renewable energy consumption and oil rent are in favor of environmental sustainability due to their negative effects on greenhouse gas emissions. However, we also found that economic growth and natural resources are harmful to environmental sustainability because of their positive effects on greenhouse gas emissions. Interestingly, compared with the results of Table 4, it was observed that the coefficients of the effects of highlighted variables on greenhouse gas emissions only changed in magnitude and significance in the statistics. In other words, the results of previous analyses are robust and reliable.

\section{Conclusions}

China plays a significant role in global concerns such as environmental sustainability, economic growth, and energy consumption. Therefore, this paper uses China as a sample to investigate the effects of highlighted variables on greenhouse gas emissions (a proxy 
for environmental sustainability) over the period 1971-2018. Employing econometric techniques to perform an empirical analysis, the results reveal that there is a long-run equilibrium relationship between highlighted variables and greenhouse gas emissions. In particular, the link between renewable energy consumption and environmental pollution reveals that a $1 \%$ increase in renewable energy consumption results in a $0.292 \%$ long-run decrease in greenhouse gas emissions and a $0.984 \%$ short-run reduction in greenhouse gas emissions. On the contrary, in the long run and short run, there is a $0.458 \%$ and $0.519 \%$ rise in economic growth-induced environmental deterioration, respectively. In addition, there is a strong positive relationship between China's total natural resources and greenhouse gas emissions. Moreover, oil rent appears to lessen the impact of environmental degradation in China, which is interesting. In addition, in a robustness test that was performed by using the fully modified ordinary least squares approach and dynamic ordinary least squares approach, the findings also support the above results.

To sum up, based on the foregoing empirical analyses of these findings, this paper may give some corresponding suggestions for China's environmental sustainability. Firstly, due to the negative effect of renewable energy consumption on greenhouse gas emissions, China's government should implement energy transformation, that is, raise the amount of renewable energy consumption so as to achieve environmental sustainability. Secondly, because of the positive effect of economic growth on greenhouse gas emissions, this serves as a reminder to China's governmental to consider its environmental effect while energetically building the economy. The reason for this is that economic development at the expense of the environment is unsustainable. Thirdly, natural resources are a strong driving force for economic growth. As the empirical results suggest, natural resources positively affect greenhouse gas emissions. Therefore, China's government should avoid excessive dependence on natural resources for economic development. Moreover, if China's government overlooks conservation and management alternatives for natural resources, this will lead to China's over-reliance on natural resources, which has an impact on environmental sustainability.

This paper looked into and added to the existing literature on China's oil-energyenvironment link. However, there is still a gap that needs to be filled as road map for future studies to develop the current literature. As a result, we recommend that future research on the topic focus on demographic variables such as democracy or population in the energy-income-oil-environment link using disaggregated data. Furthermore, while considering the research sample, this work exclusively offers China as an example. Future research might concentrate on other countries, such as the United States or Japan. In addition, this work investigates this topic only via the use of time series data. The panel data can be used in future research to re-analyze this topic. Perhaps some fresh discoveries can be made. In addition, due to the great differences in all aspects among eastern area, central area, and western area, China could be divided into these three areas for further discussions in future research.

Author Contributions: Conceptualization, Y.H. and J.W.; Methodology, Y.H.; Software, Y.H. Data curation, X.L. and P.H.; Investigation, X.L., P.H. and J.W.; Formal analysis, X.L. and P.H.; Project administration, J.W.; Supervision, J.W.; Writing—original draft, Y.H.; Writing-review and editing, X.L. and P.H. All authors have read and agreed to the published version of the manuscript.

Funding: This research received no external funding.

Institutional Review Board Statement: Not applicable.

Informed Consent Statement: Not applicable.

Data Availability Statement: The data presented in this study are available from the authors upon request.

Conflicts of Interest: The authors declare no conflict of interests. 


\section{References}

1. Sarkodie, S.A. The Invisible Hand and EKC Hypothesis: What Are the Drivers of Environmental Degradation and Pollution in Africa? Environ. Sci. Pollut. Res. 2018, 25, 21993-22022. [CrossRef] [PubMed]

2. Chen, Y.; Zhao, J.; Lai, Z.; Wang, Z.; Xia, H. Exploring the Effects of Economic Growth, and Renewable and Non-Renewable Energy Consumption on China's $\mathrm{CO}_{2}$ Emissions: Evidence from a Regional Panel Analysis. Renew. Energy 2019, 140, $341-353$. [CrossRef]

3. Dong, K.; Sun, R.; Jiang, H.; Zeng, X. $\mathrm{CO}_{2}$ Emissions, Economic Growth, and the Environmental Kuznets Curve in China: What Roles Can Nuclear Energy and Renewable Energy Play? J. Clean. Prod. 2018, 196, 51-63. [CrossRef]

4. Zhang, S.; Liu, X. The Roles of International Tourism and Renewable Energy in Environment: New Evidence from Asian Countries. Renew. Energy 2019, 139, 385-394. [CrossRef]

5. Koondhar, M.A.; Tan, Z.; Alam, G.M.; Khan, Z.A.; Wang, L.; Kong, R. Bioenergy Consumption, Carbon Emissions, and Agricultural Bioeconomic Growth: A Systematic Approach to Carbon Neutrality in China. J. Environ. Manag. 2021, $296,113242$. [CrossRef]

6. Jiang, Q.; Khattak, S.I.; Rahman, Z.U. Measuring the Simultaneous Effects of Electricity Consumption and Pro duction on Carbon Dioxide Emissions $\left(\mathrm{CO}_{2} \mathrm{e}\right)$ in China: New Evidence from an EKC-Based Assessment. Energy 2021, 229, 120616. [CrossRef]

7. Zhang, L.; Godil, D.I.; Bibi, M.; Khan, M.K.; Sarwat, S.; Anser, M.K. Caring for the Environment: How Human Capital, Natural Resources, and Economic Growth Interact with Environmental Degradation in Pakistan? A Dynamic ARDL Approach. Sci. Total Environ. 2021, 774, 145553. [CrossRef]

8. Zia, S.; ur Rahman, M.; Noor, M.H.; Khan, M.K.; Bibi, M.; Godil, D.I.; Quddoos, M.U.; Anser, M.K. Striving towards Environmental Sustainability: How Natural Resources, Human Capital, Financial Development, and Economic Growth Interact with Ecological Footprint in China. Environ. Sci. Pollut. Res. 2021, 1-15. [CrossRef]

9. Ahmad, F.; Draz, M.U.; Chang, W.-Y.; Yang, S.-C.; Su, L. More than the Resource Curse: Exploring the Nexus of Natural Resource Abundance and Environmental Quality in Northwestern China. Resour. Policy 2021, 70, 101902. [CrossRef]

10. Quan, Z.; Dongmei, B.; Xiaoxue, P. Research Status and Future Trends of Natural Resources and Sustainable Development in China: Visual Analysis Based on CiteSpace. J. Resour. Ecol. 2021, 12, 419-429. [CrossRef]

11. uz Zaman, Q.; Wang, Z.; Zaman, S.; Rasool, S.F. Investigating the Nexus between Education Expenditure, Female Employers, Renewable Energy Consumption and $\mathrm{CO}_{2}$ Emission: Evidence from China. J. Clean. Prod. 2021, 127824. [CrossRef]

12. Lei, W.; Liu, L.; Hafeez, M.; Sohail, S. Do Economic Policy Uncertainty and Financial Development Influence the Renewable Energy Consumption Levels in China? Environ. Sci. Pollut. Res. 2021, 1-10. [CrossRef] [PubMed]

13. Khan, R. Beta Decoupling Relationship between $\mathrm{CO}_{2}$ Emissions by GDP, Energy Consumption, Electricity Pro duction, ValueAdded Industries, and Population in China. PLoS ONE 2021, 16, e0249444.

14. Kirikkaleli, D.; Adebayo, T.S. Do Public-Private Partnerships in Energy and Renewable Energy Consumption Matter for Consumption-Based Carbon Dioxide Emissions in India? Environ. Sci. Pollut. Res. 2021, 1-14. [CrossRef] [PubMed]

15. Magazzino, C.; Mele, M.; Schneider, N. A Machine Learning Approach on the Relationship among Solar and Wind Energy Production, Coal Consumption, GDP, and $\mathrm{CO}_{2}$ Emissions. Renew. Energy 2021, 167, 99-115. [CrossRef]

16. Ponce, P.; Khan, S.A.R. A Causal Link between Renewable Energy, Energy Efficiency, Property Rights, and $\mathrm{CO}_{2}$ Emissions in Developed Countries: A Road Map for Environmental Sustainability. Environ. Sci. Pollut. Res. 2021, 1-14. [CrossRef]

17. Yuping, L.; Ramzan, M.; Xincheng, L.; Murshed, M.; Awosusi, A.A.; BAH, S.I.; Adebayo, T.S. Determinants of Carbon Emissions in Argentina: The Roles of Renewable Energy Consumption and Globalization. Energy Rep. 2021, 7, 4747-4760. [CrossRef]

18. Azam, A.; Rafiq, M.; Shafique, M.; Yuan, J. An Empirical Analysis of the Non-Linear Effects of Natural Gas, Nu clear Energy, Renewable Energy and ICT-Trade in Leading $\mathrm{CO}_{2}$ Emitter Countries: Policy towards $\mathrm{CO}_{2}$ Mitigation and Economic Sustainability. J. Environ. Manag. 2021, 286, 112232. [CrossRef]

19. Godil, D.I.; Yu, Z.; Sharif, A.; Usman, R.; Khan, S.A.R. Investigate the Role of Technology Innovation and Renewable Energy in Reducing Transport Sector $\mathrm{CO}_{2}$ Emission in China: A Path toward Sustainable Development. Sustain. Dev. 2021. [CrossRef]

20. Hussain, I.; Rehman, A. Exploring the Dynamic Interaction of $\mathrm{CO}_{2}$ Emission on Population Growth, Foreign Investment, and Renewable Energy by Employing ARDL Bounds Testing Approach. Environ. Sci. Pollut. Res. 2021, 28, 39387-39397. [CrossRef]

21. Zhang, Z.; Ma, X.; Lian, X.; Guo, Y.; Song, Y.; Chang, B.; Luo, L. Research on the Relationship between China's Greenhouse Gas Emissions and Industrial Structure and Economic Growth from the Perspective of Energy Consumption. Environ. Sci. Pollut. Res. 2020, 27, 41839-41855. [CrossRef] [PubMed]

22. Li, J.; Li, S. Energy Investment, Economic Growth and Carbon Emissions in China-Empirical Analysis Based on Spatial Durbin Model. Energy Policy 2020, 140, 111425. [CrossRef]

23. Zhang, X.-P.; Cheng, X.-M. Energy Consumption, Carbon Emissions, and Economic Growth in China. Ecol. Econ. 2009, 68, 2706-2712. [CrossRef]

24. Wu, Y.; Tam, V.W.; Shuai, C.; Shen, L.; Zhang, Y.; Liao, S. Decoupling China's Economic Growth from Carbon Emissions: Empirical Studies from 30 Chinese Provinces (2001-2015). Sci. Total Environ. 2019, 656, 576-588. [CrossRef] [PubMed]

25. Song, Z. Economic Growth and Carbon Emissions: Estimation of a Panel Threshold Model for the Transition Process in China. J. Clean. Prod. 2021, 278, 123773. [CrossRef]

26. Bekun, F.V.; Alola, A.A.; Sarkodie, S.A. Toward a Sustainable Environment: Nexus between $\mathrm{CO}_{2}$ Emissions, Re source Rent, Renewable and Nonrenewable Energy in 16-EU Countries. Sci. Total Environ. 2019, 657, 1023-1029. [CrossRef] 
27. Muhammad, B.; Khan, M.K.; Khan, M.I.; Khan, S. Impact of Foreign Direct Investment, Natural Resources, Renewable Energy Consumption, and Economic Growth on Environmental Degradation: Evidence from BRICS, Developing, Developed and Global Countries. Environ. Sci. Pollut. Res. 2021, 28, 21789-21798. [CrossRef]

28. Agboola, M.O.; Bekun, F.V.; Joshua, U. Pathway to Environmental Sustainability: Nexus between Economic Growth, Energy Consumption, $\mathrm{CO}_{2}$ Emission, Oil Rent and Total Natural Resources Rent in Saudi Arabia. Resour. Policy 2021, 74, 102380. [CrossRef]

29. Usman, M.; Jahanger, A.; Makhdum, M.S.A.; Balsalobre-Lorente, D.; Bashir, A. How Do Financial Development, Energy Consumption, Natural Resources, and Globalization Affect Arctic Countries' Economic Growth and Environmental Quality? An Advanced Panel Data Simulation. Energy 2021, 122515. [CrossRef]

30. Topcu, E.; Altinoz, B.; Aslan, A. Global Evidence from the Link between Economic Growth, Natural Resources, Energy Consumption, and Gross Capital Formation. Resour. Policy 2020, 66, 101622. [CrossRef]

31. Ulucak, R.; Ozcan, B. Relationship between Energy Consumption and Environmental Sustainability in OECD Countries: The Role of Natural Resources Rents. Resour. Policy 2020, 69, 101803. [CrossRef]

32. Khan, I.; Hou, F.; Le, H.P. The Impact of Natural Resources, Energy Consumption, and Population Growth on Environmental Quality: Fresh Evidence from the United States of America. Sci. Total Environ. 2021, 754, 142222. [CrossRef] [PubMed]

33. Adedoyin, F.F.; Gumede, M.I.; Bekun, F.V.; Etokakpan, M.U.; Balsalobre-Lorente, D. Modelling Coal Rent, Economic Growth and $\mathrm{CO}_{2}$ Emissions: Does Regulatory Quality Matter in BRICS Economies? Sci. Total Environ. 2020, 710, 136284. [CrossRef]

34. Zaman, K.; Abdullah, I.; Ali, M. Decomposing the Linkages between Energy Consumption, Air Pollution, Climate Change, and Natural Resource Depletion in P Akistan. Environ. Prog. Sustain. Energy 2017, 36, 638-648. [CrossRef]

35. Hassan, S.T.; Xia, E.; Khan, N.H.; Shah, S.M.A. Economic Growth, Natural Resources, and Ecological Footprints: Evidence from Pakistan. Environ. Sci. Pollut. Res. 2019, 26, 2929-2938. [CrossRef] [PubMed]

36. Joshua, U.; Bekun, F.V. The Path to Achieving Environmental Sustainability in South Africa: The Role of Coal Consumption, Economic Expansion, Pollutant Emission, and Total Natural Resources Rent. Environ. Sci. Pollut. Res. 2020, 27, 9435-9443. [CrossRef]

37. Gyamfi, B.A.; Adedoyin, F.F.; Bein, M.A.; Bekun, F.V.; Agozie, D.Q. The Anthropogenic Consequences of Energy Consumption in E7 Economies: Juxtaposing Roles of Renewable, Coal, Nuclear, Oil and Gas Energy: Evidence from Panel Quantile Method. J. Clean. Prod. 2021, 295, 126373. [CrossRef]

38. Ahmed, Z.; Asghar, M.M.; Malik, M.N.; Nawaz, K. Moving towards a Sustainable Environment: The Dynamic Linkage between Natural Resources, Human Capital, Urbanization, Economic Growth, and Ecological Footprint in China. Resour. Policy 2020, 67, 101677. [CrossRef]

39. Baloch, M.A.; Mahmood, N.; Zhang, J.W. Effect of Natural Resources, Renewable Energy and Economic Development on $\mathrm{CO}_{2}$ Emissions in BRICS Countries. Sci. Total Environ. 2019, 678, 632-638.

40. Khan, M.K.; Teng, J.-Z.; Khan, M.I. Effect of Energy Consumption and Economic Growth on Carbon Dioxide Emissions in Pakistan with Dynamic ARDL Simulations Approach. Environ. Sci. Pollut. Res. 2019, 26, 23480-23490. [CrossRef]

41. Mahmood, H.; Furqan, M. Oil Rents and Greenhouse Gas Emissions: Spatial Analysis of Gulf Cooperation Council Countries. Environ. Dev. Sustain. 2021, 23, 6215-6233. [CrossRef]

42. Ozturk, I. Measuring the Impact of Alternative and Nuclear Energy Consumption, Carbon Dioxide Emissions and Oil Rents on Specific Growth Factors in the Panel of Latin American Countries. Prog. Nucl. Energy 2017, 100, 71-81. [CrossRef]

43. Sadik-Zada, E.R.; Loewenstein, W. Drivers of $\mathrm{CO}_{2}$-Emissions in Fossil Fuel Abundant Settings:(Pooled) Mean Group and Nonparametric Panel Analyses. Energies 2020, 13, 3956. [CrossRef]

44. Ike, G.N.; Usman, O.; Sarkodie, S.A. Testing the Role of Oil Production in the Environmental Kuznets Curve of Oil Producing Countries: New Insights from Method of Moments Quantile Regression. Sci. Total Environ. 2020, 711, 135208. [CrossRef] [PubMed]

45. Mahmood, H.; Alkhateeb, T.T.Y.; Furqan, M. Oil Sector and CO 2 Emissions in Saudi Arabia: Asymmetry Analysis. Palgrave Commun. 2020, 6, 1-10. [CrossRef]

46. Shen, Y.; Su, Z.-W.; Malik, M.Y.; Umar, M.; Khan, Z.; Khan, M. Does Green Investment, Financial Development and Natural Resources Rent Limit Carbon Emissions? A Provincial Panel Analysis of China. Sci. Total Environ. 2021, 755, 142538. [CrossRef]

47. Agboola, M.O.; Bekun, F.V.; Balsalobre-Lorente, D. Implications of Social Isolation in Combating COVID-19 Outbreak in Kingdom of Saudi Arabia: Its Consequences on the Carbon Emissions Reduction. Sustainability 2021, 13, 9476. [CrossRef]

48. Anser, M.K.; Yousaf, Z.; Zaman, K.; Nassani, A.A.; Alotaibi, S.M.; Jambari, H.; Khan, A.; Kabbani, A. Determination of Resource Curse Hypothesis in Mediation of Financial Development and Clean Energy Sources: Go-for-Green Resource Policies. Resour. Policy 2020, 66, 101640. [CrossRef]

49. Sohoo, I.; Ritzkowski, M.; Kuchta, K.; Cinar, S.Ö. Environmental Sustainability Enhancement of Waste Disposal Sites in Developing Countries through Controlling Greenhouse Gas Emissions. Sustainability 2021, 13, 151. [CrossRef]

50. Alola, A.A.; Akadiri, S.S.; Usman, O. Domestic Material Consumption and Greenhouse Gas Emissions in the EU-28 Countries: Implications for Environmental Sustainability Targets. Sustain. Dev. 2021, 29, 388-397. [CrossRef]

51. Sarkodie, S.A.; Strezov, V.; Weldekidan, H.; Asamoah, E.F.; Owusu, P.A.; Doyi, I.N.Y. Environmental Sustainability Assessment Using Dynamic Autoregressive-Distributed Lag Simulations-Nexus between Greenhouse Gas Emissions, Biomass Energy, Food and Economic Growth. Sci. Total Environ. 2019, 668, 318-332. [CrossRef] [PubMed] 
52. Kaygusuz, K. Energy and Environmental Issues Relating to Greenhouse Gas Emissions for Sustainable Development in Turkey. Renew. Sustain. Energy Rev. 2009, 13, 253-270. [CrossRef]

53. Vasylieva, T.; Lyulyov, O.; Bilan, Y.; Streimikiene, D. Sustainable Economic Development and Greenhouse Gas Emissions: The Dynamic Impact of Renewable Energy Consumption, GDP, and Corruption. Energies 2019, 12, 3289. [CrossRef]

54. Lyeonov, S.; Pimonenko, T.; Bilan, Y.; Štreimikienè, D.; Mentel, G. Assessment of Green Investments' Impact on Sustainable Development: Linking Gross Domestic Product per Capita, Greenhouse Gas Emissions and Renewable Energy. Energies 2019, 12, 3891. [CrossRef]

55. Squalli, J. Renewable Energy, Coal as a Baseload Power Source, and Greenhouse Gas Emissions: Evidence from US State-Level Data. Energy 2017, 127, 479-488. [CrossRef]

56. Lapinskienė, G.; Peleckis, K.; Slavinskaite, N. Energy Consumption, Economic Growth and Greenhouse Gas Emissions in the European Union Countries. J. Bus. Econ. Manag. 2017, 18, 1082-1097. [CrossRef]

57. Lu, W.-C. Greenhouse Gas Emissions, Energy Consumption and Economic Growth: A Panel Cointegration Analysis for 16 Asian Countries. Int. J. Environ. Res. Public. Health 2017, 14, 1436. [CrossRef]

58. Kim, S. The Effects of Foreign Direct Investment, Economic Growth, Industrial Structure, Renewable and Nuclear Energy, and Urbanization on Korean Greenhouse Gas Emissions. Sustainability 2020, 12, 1625. [CrossRef]

59. Morrow, W.R.; Gallagher, K.S.; Collantes, G.; Lee, H. Analysis of Policies to Reduce Oil Consumption and Greenhouse-Gas Emissions from the US Transportation Sector. Energy Policy 2010, 38, 1305-1320. [CrossRef]

60. Van Ruijven, B.; Van Vuuren, D.P. Oil and Natural Gas Prices and Greenhouse Gas Emission Mitigation. Energy Policy 2009, 37, 4797-4808. [CrossRef]

61. Germer, J.; Sauerborn, J. Estimation of the Impact of Oil Palm Plantation Establishment on Greenhouse Gas Balance. Environ. Dev. Sustain. 2008, 10, 697-716. [CrossRef]

62. Tufail, M.; Song, L.; Adebayo, T.S.; Kirikkaleli, D.; Khan, S. Do Fiscal Decentralization and Natural Resources Rent Curb Carbon Emissions? Evidence from Developed Countries. Environ. Sci. Pollut. Res. 2021, 28, 49179-49190. [CrossRef] [PubMed]

63. Huang, S.-Z.; Sadiq, M.; Chien, F. The Impact of Natural Resource Rent, Financial Development, and Urbanization on Carbon Emission. Environ. Sci. Pollut. Res. 2021, 1-13. [CrossRef] [PubMed]

64. Sterpu, M.; Soava, G.; Mehedintu, A. Impact of Economic Growth and Energy Consumption on Greenhouse Gas Emissions: Testing Environmental Curves Hypotheses on EU Countries. Sustainability 2018, 10, 3327. [CrossRef]

65. Pesaran, M.H.; Shin, Y.; Smith, R.J. Bounds Testing Approaches to the Analysis of Level Relationships. J. Appl. Econom. 2001, 16, 289-326. [CrossRef]

66. Pesaran, M.H.; Shin, Y. An Autoregressive Distributed Lag Modelling Approach to Cointegration Analysis; University of Cambridge: Cambridge, UK, 1995.

67. Narayan, P.; Smyth, R. Trade Liberalization and Economic Growth in Fiji. An Empirical Assessment Using the ARDL Approach. J. Asia Pac. Econ. 2005. [CrossRef]

68. Persan, M.H.; Pesaran, B. Microfit 4.0: Interactive Econometric Analysis; Oxford University Press: Oxford, UK, 1997.

69. Lee, J.; Strazicich, M.C. Break Point Estimation and Spurious Rejections with Endogenous Unit Root Tests. Oxf. Bull. Econ. Stat. 2001, 63, 535-558. [CrossRef]

70. Harvey, D.I.; Leybourne, S.J.; Newbold, P. Innovational Outlier Unit Root Tests with an Endogenously Determined Break in Level. Oxf. Bull. Econ. Stat. 2001, 63, 559-575. [CrossRef]

71. Carrion-i-Silvestre, J.L.; Sanso-i-Rossello, A.; Ortuño, M.A. Unit Root and Stationarity Tests' Wedding. Econ. Lett. 2001, 70, 1-8. [CrossRef]

72. Xiao, Z. Testing the Null Hypothesis of Stationarity against an Autoregressive Unit Root Alternative. J. Time Ser. Anal. 2001, 22, 87-105. [CrossRef]

73. Shafiullah, M.; Khalid, U.; Shahbaz, M. Does Meat Consumption Exacerbate Greenhouse Gas Emissions? Evidence from US Data. Environ. Sci. Pollut. Res. 2021, 28, 11415-11429. [CrossRef] [PubMed]

74. Hundie, S.K. Income Inequality, Economic Growth and Carbon Dioxide Emissions Nexus: Empirical Evidence from Ethiopia. Environ. Sci. Pollut. Res. 2021, 28, 43579-43598. [CrossRef] [PubMed]

75. Sun, C.; Zhang, F.; Xu, M. Investigation of Pollution Haven Hypothesis for China: An ARDL Approach with Breakpoint Unit Root Tests. J. Clean. Prod. 2017, 161, 153-164. [CrossRef]

76. Pata, U.K.; Caglar, A.E. Investigating the EKC Hypothesis with Renewable Energy Consumption, Human Capital, Globalization and Trade Openness for China: Evidence from Augmented ARDL Approach with a Structural Break. Energy 2021, 216, 119220. [CrossRef]

77. Zhijun, F.; Nailing, Y. Putting a Circular Economy into Practice in China. Sustain. Sci. 2007, 2, 95-101. [CrossRef]

78. Geng, Y.; Doberstein, B. Developing the Circular Economy in China: Challenges and Opportunities for Achieving' leapfrog Development'. Int. J. Sustain. Dev. World Ecol. 2008, 15, 231-239. [CrossRef]

79. Chen, Y.; Wang, Z.; Zhong, Z. $\mathrm{CO}_{2}$ Emissions, Economic Growth, Renewable and Non-Renewable Energy Production and Foreign Trade in China. Renew. Energy 2019, 131, 208-216. [CrossRef]

80. Dong, K.; Dong, X.; Jiang, Q. How Renewable Energy Consumption Lower Global $\mathrm{CO}_{2}$ Emissions? Evidence from Countries with Different Income Levels. World Econ. 2020, 43, 1665-1698. [CrossRef] 
81. Wang, S.; Li, Q.; Fang, C.; Zhou, C. The Relationship between Economic Growth, Energy Consumption, and $\mathrm{CO}_{2}$ Emissions: Empirical Evidence from China. Sci. Total Environ. 2016, 542, 360-371. [CrossRef]

82. Govindaraju, V.C.; Tang, C.F. The Dynamic Links between $\mathrm{CO}_{2}$ Emissions, Economic Growth and Coal Consumption in China and India. Appl. Energy 2013, 104, 310-318. [CrossRef]

83. He, K.; Huo, H.; Zhang, Q.; He, D.; An, F.; Wang, M.; Walsh, M.P. Oil Consumption and $\mathrm{CO}_{2}$ Emissions in China's Road Transport: Current Status, Future Trends, and Policy Implications. Energy Policy 2005, 33, 1499-1507. [CrossRef]

84. Saboori, B.; Rasoulinezhad, E.; Sung, J. The Nexus of Oil Consumption, CO 2 Emissions and Economic Growth in China, Japan and South Korea. Environ. Sci. Pollut. Res. 2017, 24, 7436-7455. [CrossRef] [PubMed]

85. Alam, M.S.; Paramati, S.R. Do Oil Consumption and Economic Growth Intensify Environmental Degradation? Evidence from Developing Economies. Appl. Econ. 2015, 47, 5186-5203. [CrossRef]

86. Chen, G.Q.; Chen, Z.M. Greenhouse Gas Emissions and Natural Resources Use by the World Economy: Ecological Input-Output Modeling. Ecol. Model. 2011, 222, 2362-2376. [CrossRef]

87. Balsalobre-Lorente, D.; Shahbaz, M.; Roubaud, D.; Farhani, S. How Economic Growth, Renewable Electricity and Natural Resources Contribute to $\mathrm{CO}_{2}$ Emissions? Energy Policy 2018, 113, 356-367. [CrossRef]

88. Zhou, S.Y.; Chen, H.; Li, S.C. Resources Use and Greenhouse Gas Emissions in Urban Economy: Ecological Input-Output Modeling for Beijing 2002. Commun. Nonlinear Sci. Numer. Simul. 2010, 15, 3201-3231. [CrossRef]

89. Anwar, A.; Siddique, M.; Dogan, E.; Sharif, A. The Moderating Role of Renewable and Non-Renewable Energy in EnvironmentIncome Nexus for ASEAN Countries: Evidence from Method of Moments Quantile Regression. Renew. Energy 2021, 164, 956-967. [CrossRef]

90. Yao, S.; Zhang, S.; Zhang, X. Renewable Energy, Carbon Emission and Economic Growth: A Revised Environ mental Kuznets Curve Perspective. J. Clean. Prod. 2019, 235, 1338-1352. [CrossRef]

91. Wolde-Rufael, Y.; Idowu, S. Income Distribution and $\mathrm{CO}_{2}$ Emission: A Comparative Analysis for China and India. Renew. Sustain. Energy Rev. 2017, 74, 1336-1345. [CrossRef] 